\title{
Direct Chemical Evidence for Charge Transfer between Photoexcited 2- Aminopurine and Guanine in Duplex DNA
}

Melanie A. O’Neill, Chikara Dohno and Jacqueline K. Barton

Division of Chemistry and Chemical Engineering

California Institute of Technology,

Pasadena, California 91125

\section{Supporting Information}

Figure S-1. Reverse phase HPLC (C18, 2-14\% acetonitrile in $50 \mathrm{mM}$ ammonium acetate over 30 minutes) traces profiling the decomposition of ${ }^{\mathrm{CP}} \mathrm{G}$ as a function of irradiation time ( $325 \mathrm{~nm}, \sim 3 \mathrm{~mW}$ ) for $5 \square \mathrm{M} \mathrm{ApAAC}{ }^{\mathrm{CP}} \mathrm{G}$ duplexes in $100 \mathrm{mM}$ sodium phosphate $\mathrm{pH}$ 7. Expanded region shows formation of ${ }^{\mathrm{HP}} \mathrm{G}$ as a function of increasing irradiation time. These traces are representative of those observed for all $\mathrm{Ap} / \mathrm{CP}_{\mathrm{G}}$ duplexes with the exception of $\mathrm{ApC}^{\mathrm{CP}} \mathrm{G}$ and $\mathrm{ApA}^{\mathrm{CP}} \mathrm{G}$ for which no photodecomposition was observed.

Figure S-2. Fluorescence emission spectra $\left(\square_{\mathrm{ex}}=325 \mathrm{~nm}\right)$ of $5 \square \mathrm{M} \mathrm{Ap} / \mathrm{CP}_{\mathrm{G}}$ duplexes in $100 \mathrm{mM}$ sodium phosphate $\mathrm{pH} 7$. All duplexes are dramatically less emissive $(<5 \%)$ than free Ap under the same conditions. The following trends in the relative quenching of Ap within the DNA duplexes are noted: $\mathrm{ApAG}>\mathrm{ApA}^{\mathrm{CP}} \mathrm{G}$; $\mathrm{ApAAA}{ }^{\mathrm{CP}} \mathrm{G}>\mathrm{ApA}^{\mathrm{CP}} \mathrm{G}$; ApAAAAC ${ }^{\mathrm{CP}} \mathrm{G}-\mathrm{A}-\mathrm{A}$ mismatch $>$ ApAAAAC ${ }^{\mathrm{CP}} \mathrm{G}>\mathrm{ApAAC}^{\mathrm{CP}} \mathrm{G}$. These are consistent

with the influence of donor $\left(\mathrm{G}\right.$, or $\left.{ }^{\mathrm{CP}} \mathrm{G}\right)$ distance and oxidation potential $\left({ }^{\mathrm{CP}} \mathrm{G}<\mathrm{G}\right)$, neighboring bases (purines versus pyrimidines) and nearby mismatches on Ap* emission intensity. 
Figure S-3. Normalized fluorescence excitation spectra $\left(\square_{\mathrm{em}}=370 \mathrm{~nm}\right)$ of Ap and $\mathrm{Ap} / \mathrm{CP}_{\mathrm{G}}$ duplexes. Samples are $5 \square \mathrm{M}$ in $100 \mathrm{mM}$ sodium phosphate $\mathrm{pH}$ 7. The long wavelength band, due to direct excitation of Ap is redshifted in DNA. The magnitude of this shift reflects the reduction in solvent exposure of Ap within the duplex. The short wavelength band is due to energy transfer from the natural DNA bases; stronger stacking interactions facilitate more efficient energy transfer. Both the relative redshift and the relative intensity of the energy transfer band increase in the following order: Ap < $\mathrm{ApC}^{\mathrm{CP}} \mathrm{G}<\mathrm{ApA}^{\mathrm{CP}} \mathrm{G}=\mathrm{ApAG}$. This indicates that Ap does not sense the substitution of ${ }^{\mathrm{CP}} \mathrm{G}$ for $\mathrm{G}$, and that as with $\mathrm{G}$, stacking interactions of $\mathrm{Ap}$ in ${ }^{\mathrm{CP}} \mathrm{G}$ duplexes are stronger with A than with $\mathrm{C}$.

Table S-1. Melting temperatures $\left(\mathrm{T}_{\mathrm{m}}\right)$ of $\mathrm{Ap} / \mathrm{CP}_{\mathrm{G}}$ duplexes $(3 \square \mathrm{M}$ in $100 \mathrm{mM}$ sodium phosphate $\mathrm{pH} 7$ ) determined by monitoring the change in absorption at $260 \mathrm{~nm}$ as a function of temperature $\left(0.5^{\circ} \mathrm{C}\right.$ /minute). The $\mathrm{T}_{\mathrm{m}}$ corresponds to the maximum $\square \mathrm{A} / \square \mathrm{T}$. In duplex 7, the A-A mismatch is at the third A from the 5'-end. Note that duplexes 4-7 have a slightly higher GC content (exchange of one GC for AT pair) than duplexes 1-3 leading to a small increase in duplex stabilization.

\begin{tabular}{|c|l|c|}
\hline Number & Duplex & $\mathrm{T}_{\mathrm{m}}\left({ }^{\circ} \mathrm{C}\right)$ \\
1 & ApAG & 65 \\
2 & ApACP $_{\mathrm{C}}$ & 64 \\
3 & ApAAA $_{\mathrm{G}}$ & 65 \\
4 & ApC $_{\mathrm{CP}}$ & 68 \\
5 & ApAAC $_{\mathrm{G}}$ & 68 \\
6 & ApAAAAC $_{\mathrm{G}}$ & 68 \\
7 & ApAAAAC & 65 \\
\hline
\end{tabular}



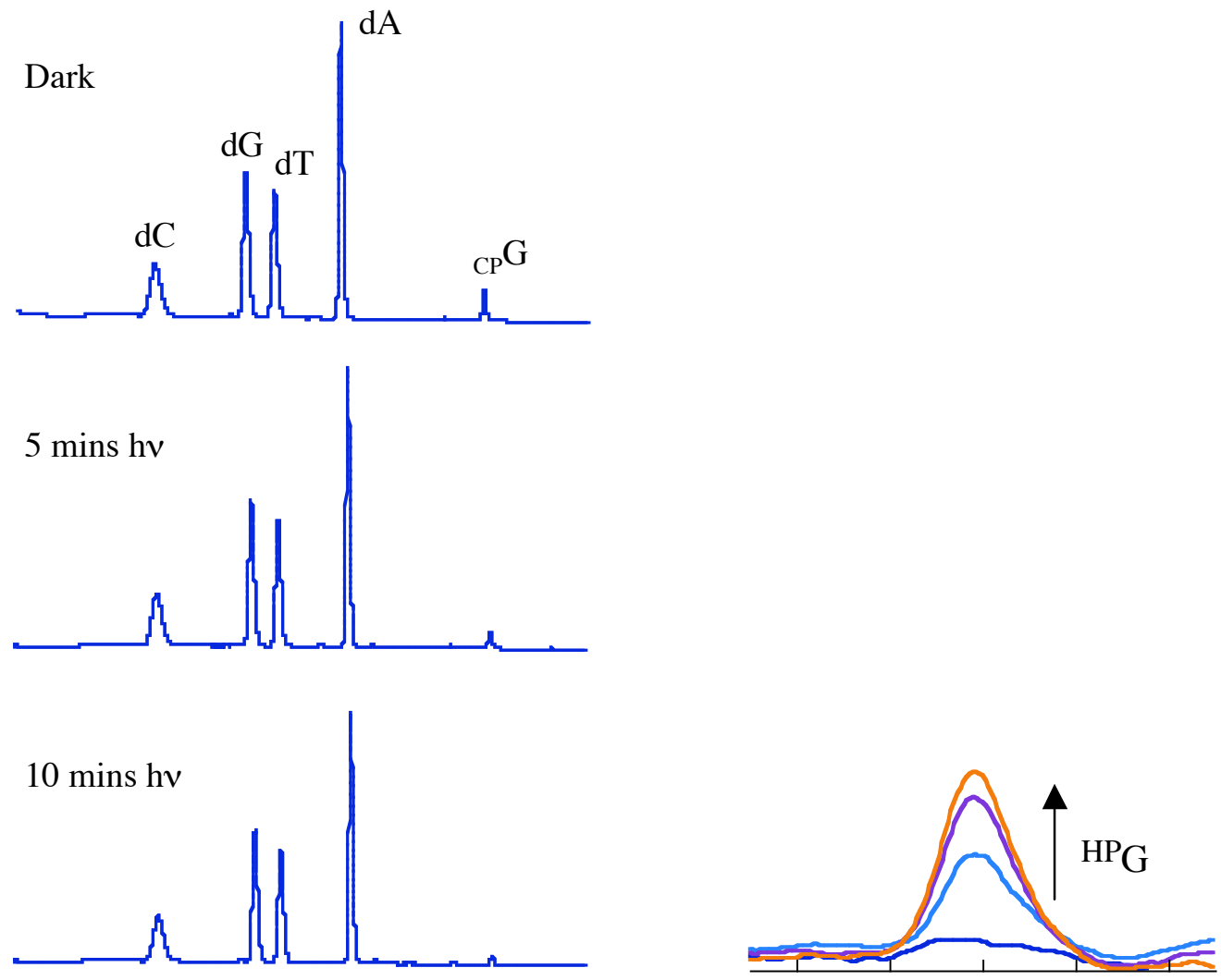

$15 \min \mathrm{h} \square$
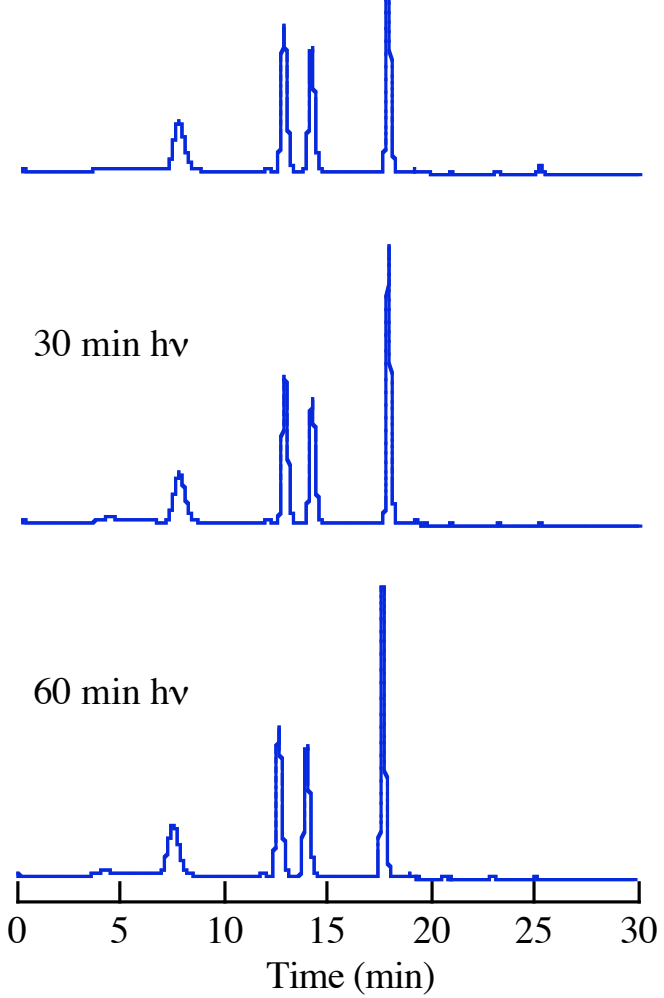

Figure S-1 

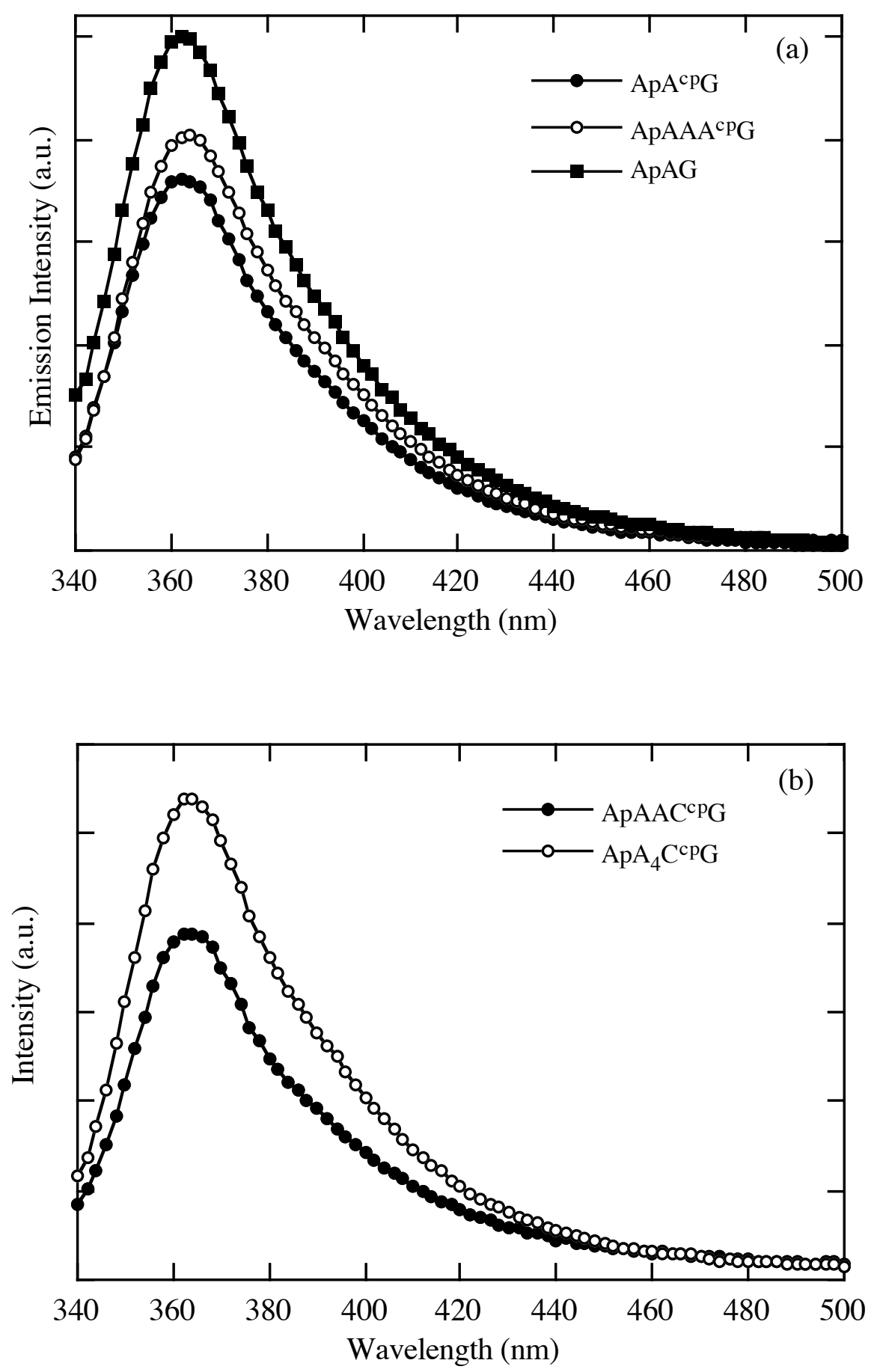

Figure S-2 


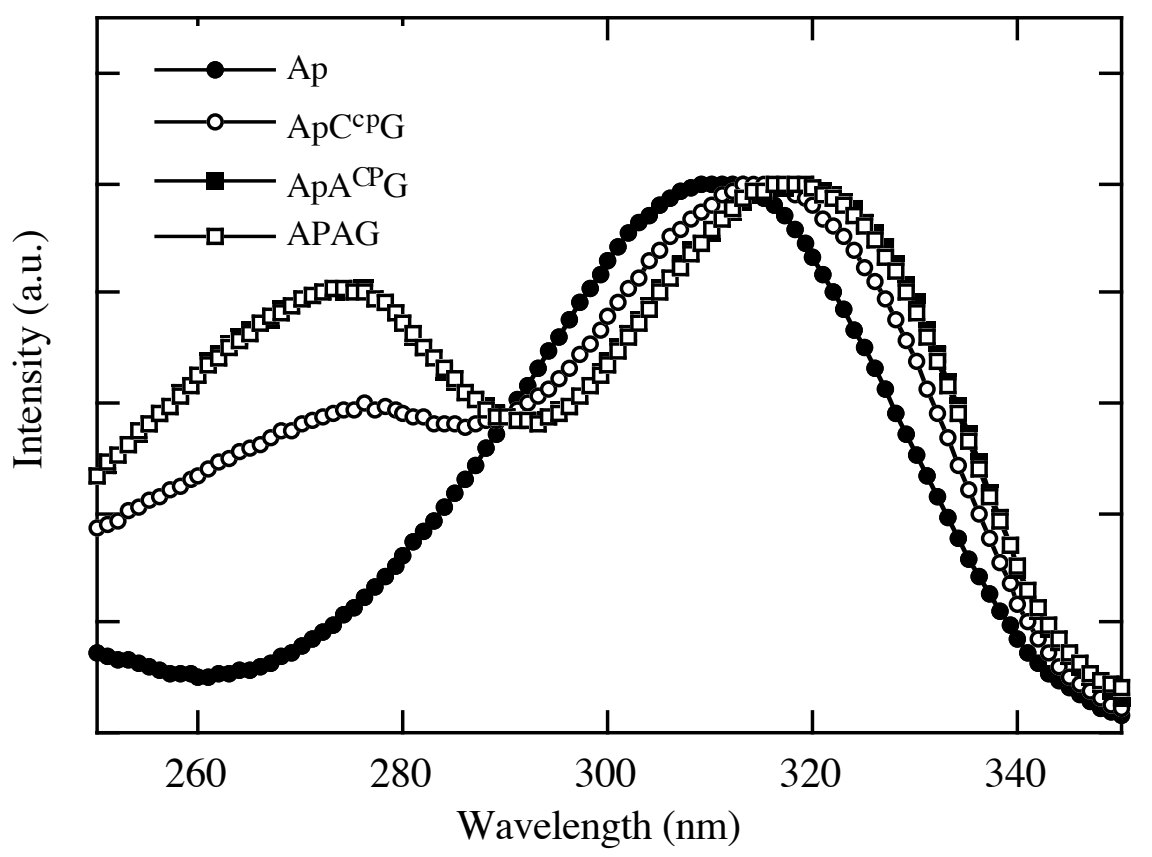

Figure S-3 